\title{
Hubungan Massa Lemak dengan Dismenore Primer pada Remaja Putri di Stikes Ceria Buana Bukittinggi
}

\author{
Lini gustini ${ }^{1}$, Nur Indrawaty Lipoeto ${ }^{2}$, Bobby Indra Utama ${ }^{3}$
}

\begin{abstract}
Abstrak
Nyeri haid (dismenore) dilaporkan sebagai keluhan ginekologis paling umum dan sering menyebabkan ketidakhadiran seorang remaja dari sekolah ataupun aktivitas lainnya. Penyebab dismenore primer ada banyak faktor salah satunya adalah massa lemak tubuh. Tujuan penelitian ini adalah menentukan hubungan massa lemak dengan dismenore primer. Penelitian observasional ini dilakukan pada remaja putri di Stikes Ceria Buana Bukittinggi dengan desain cross sectional study. Jumlah subjek dalam penelitian ini adalah 106 orang yang diambil secara simpel random sampling. Hasil penelitian ini diuji dengan menggunakan uji statistik $t$-test. Dari hasil penelitian ini didapatkan bahwa tidak ada perbedaan yang bermakna $(p>0,05)$ antara massa lemak remaja putri yang dismenore primer $(30,79 \pm 5,99 \%)$ dengan massa lemak remaja yang tidak dismenore primer $(31,50 \pm 6,42 \%)$. Simpulan penelitian ini adalah tidak terdapat hubungan yang bermakna antara massa lemak dengan dismenore primer pada remaja putri di Stikes Ceria Buana Bukittinggi.
\end{abstract}

Kata kunci: remaja putri, massa lemak, dismenore primer

\section{Abstract}

Dysmenorrhea is reported as the most common gynecological complaints and often lead to the absence of a teenager from school or other activities. Causes of primary dysmenorrhea there are many factors one of which is body fat mass. The objective of this study was to determine the relationship between fat mass and primary dysmenorrhea. This study was conducted on young women in Stikes Ceria Buana with cross sectional study design. The number of subjects in this study a total of 106 people taken by simple random sampling. Results of this study were tested using statistical test $t$-test. The results of this study showed that there was no significant difference $(p>0.05)$ between the fat mass of young women who are primary dysmenorrhea $(30.79 \pm 5.99 \%)$ and fat mass teenagers who are not of primary dysmenorrhea $(31.50 \pm 6.42 \%)$. It is concluded that there is no significant correlation between fat mass with primary dysmenorrhea in adolescent girls in Stikes Ceria Buana Bukittinggi.

Keywords: Young women, fat mass, primary dysmenorhrea

Affiliasi penulis: 1. Program Studi Magister S2 Kebidanan FK Unand (Fakultas Kedokteran Universitas Andalas Padang), 2. Bagian Kesehatan Masyarakat FK Unand 3. Bagian Obstetri Ginekologi FK Unand/RSUP DR.M. Djamil,

Korespondensi: Lini Gustini ,Email: gustinilini@yahoo.com

\section{PENDAHULUAN}

Masa remaja adalah masa puncak pertumbuhan seseorang. Pada usia ini aktivitas fisik tergolong tinggi, sehingga remaja memerlukan kondisi kesehatan fisik dan emosional yang maksimal agar mampu melakukan aktivitas yang padat. ${ }^{1}$ Pada remaja putri yang tiap bulannya kehilangan darah melalui proses menstruasi, sehingga rentan terjadi gangguan akibat kekurangan zat gizi apabila asupan zat gizi dan kesehatan tidak dijaga. ${ }^{2}$

Nyeri pada saat menstruasi (dismenore) adalah nyeri yang timbul akibat kontraksi disritmik miometrium dengan satu atau dua gejala mulai dari nyeri ringan sampai nyeri berat pada perut bagian bawah, bokong dan paha. Dismenore dapat diklasifikasikan menjadi dismenore primer dan dismenore sekunder. ${ }^{3}$ Dismenore primer yaitu nyeri 
haid yang berhubungan erat dengan ketidak seimbangan steroid seks ovarium tanpa adanya kelainan organ, sedangkan dismenore sekunder yaitu nyeri haid karena adanya kelainan organ dalam pelvis. ${ }^{4}$

Angka kejadian dismenore di dunia sangat besar. Rata-rata lebih dari $50 \%$ perempuan mengalami dismenore primer. Di Amerika angka presentasinya sekitar $60 \%$ dan di Swedia sekitar $72 \%{ }^{5} \mathrm{Di}$ Indonesia angkanya diperkirakan 55\% perempuan produktif yang tersiksa oleh dismenore. Angka kejadian dismenore berkisar $45-55 \%$ di kalangan wanita usia produktif. ${ }^{6}$

Dismenore primer primer dialami oleh $60-75 \%$ wanita muda. Pada $75 \%$ wanita yang mengalami intensitas kram ringan atau sedang, sedangkan pada $25 \%$ nyeri berat dan membuat penderita tidak berdaya. Dismenore primer biasanya terjadi pada perempuan muda nulipara dengan pemeriksaan panggul norma. ${ }^{7}$ Dismenore sekunder lebih jarang ditemukan dan terjadi pada $25 \%$ wanita yang mengalami dismenore dan penyebabnya adalah endometritis, fibroid, adenomiosis, peradangan tuba fallopi, perlekatan abnormal antara organ diperut dan pemakaian IUD (Intra Uterin Device). ${ }^{8}$

Astuti pada tahun 2005, menyatakan bahwa dismenore akan meningkat pada wanita yang mangalami kegemukan, kurang nutrisi, peminum kopi dan alkohol, perokok, tidak aktif secara seksual , tidak pernah melahirkan dan juga dialami oleh wanita yang dalam keluarga mempunyai riwayat dismenore. ${ }^{9}$ Olahraga dapat mengurangi nyeri dismenore, dapat segera menghilang setelah perkawinan dan jarang menetap setelah melahirkan. ${ }^{10}$

Status gizi merupakan faktor risiko terjadinya dismenore primer. Pada wanita yang memilki kelebihan berat badan terjadi hyperplasia pembuluh darah pada organ reproduksi sehingga dapat mengakibatkan dismenore primer. ${ }^{11}$ Wanita dengan indeks massa tubuh lebih dari normal memiliki kadar prostaglandin yang tinggi dapat memicu terjadinya dismenore primer. ${ }^{12}$

Bioelectrical Impedance Analysis merupakan suatu metode untuk mengukur komposisi tubuh. ${ }^{13}$ Penggunaan BIA ini cukup mudah, karena saat ini metode BIA juga divalidasi untuk populasi pediatrik atau anak-anak. Pengukuran BIA untuk mengukur lemak tubuh menggunakan BB, TB, umur dan jenis kelamin sebagai parameter. BIA ini mudah digunakan, murah dan diproduksi secara massal. ${ }^{14}$

Hasil penelitian Pasco et al (2014) di Australia mendapatkan hubungan yang bermakna antara overweight dengan kejadian dismenore primer. ${ }^{15}$

Hasil penelitian Madhubala dan Kala (2012) di India ada hubungan yang bermakna antara underweight dengan dismenore primer. ${ }^{16}$ Begitu juga hasil penelitian Ranasinghe et al (2013) di Sri Langka ada hubungan yang bermakna antara underweight dengan dismenore primer. ${ }^{17}$

Berdasarkan data dari Sekolah Tinggi IImu Kesehatan Ceria Buana jumlah remaja putri sebanyak 180 orang. Telah dilakukan studi pendahuluan terhadap 10 orang remaja putri di STIkes Ceria Buana, 6 orang mengalami dismenore primer $(60 \%)$. Penelitian tentang hubungan massa lemak dengan dismenore primer jarang dilakukan di Indonesia, termasuk di Sumatera Barat, terutama di Stikes Ceria Buana sendiri belum pernah diadakannya penelitian ini. Selain itu beberapa hasil penelitian tentang hubungan massa lemak dengan dismenore primer tidak konsisten dan bervariasi, sehingga penulis merasa perlu melakukan penelitian lebih lanjut.

\section{METODE}

Studi ini adalah penelitian observasional dengan rancangan cross sectional (potong lintang). .Penelitian dilakukan di Stikes Ceria Buana Bukittinggi. Populasi adalah semua mahasiswa Stikes Ceria Buana yang terdaftar pada tahun ajaran 20142015. Subjek dalam penelitian ini adalah seluruh remaja putri di Stikes Ceria Buana yang berusia 18-25 tahun dengan siklus menstruasi ovulatoir, mampu berkomunikasi verbal maupun non verbal yang diambil secara simpel random sampling sebanyak 106 orang. Pemeriksaan massa lemak menggunakan timbangan TANITA. Penelitian ini telah mendapatkan persetujuan etik dari Komite Etika Penelitian Fakultas Kedokteran Unand no.024/KEP/FK/2015. Data yang diperoleh dianalisa dengan uji $t$ independen 
HASIL.

Tabel 1. Distribusi karakteristik responden dismenore primer dan tidak dismenore primer

\begin{tabular}{lccccc}
\hline \multirow{2}{*}{ Karakteristik } & \multicolumn{2}{c}{ Dismenore } & \multicolumn{2}{c}{ Tidak } \\
& Mismenore & p \\
& Mean & SD & Mean & SD \\
\hline Umur & 20,47 & 1,16 & 20,50 & 1,58 & 0,94 \\
Berat Badan & 53,65 & 9,94 & 53,81 & 6,64 & 0,96 \\
Tinggi Badan & 155,26 & 5,75 & 154,30 & 5,89 & 0,62 \\
IMT & 22,19 & 3,48 & 22,55 & 1,74 & 0,75 \\
Usia & & & & & \\
Menarche & 13.08 & 1,15 & 13,10 & 1,10 & 0,97 \\
\hline
\end{tabular}

Tabel 2. Distribusi frekuensi massa lemak responden penelitian

\begin{tabular}{ccc}
\hline Massa Lemak & Frekuensi & $\begin{array}{c}\text { Persentase } \\
\text { (\%) }\end{array}$ \\
\hline$<21 \%$ & 2 & 1,9 \\
$21 \%-33 \%$ & 65 & 61,3 \\
$>33 \%$ & 39 & 36,8 \\
Total & 106 & 100 \\
\hline
\end{tabular}

Tabel 3. Distribusi frekuensi dismenore primer responden penelitian

\begin{tabular}{lrc}
\hline Dismenore primer & Frekuensi & $\begin{array}{c}\text { Persentase } \\
\text { (\%) }\end{array}$ \\
\hline Tdk Dismenore & 10 & 9.4 \\
DismenoreRingan & 55 & 51.9 \\
DismenoreSedang & 3 & 2,8 \\
Dismenore Berat & 38 & 35.8 \\
\multicolumn{1}{c}{ Total } & 106 & 100 \\
\hline
\end{tabular}

Tabel 4. Hubungan massa lemak reponden dengan dismenore primer

\begin{tabular}{lcccc}
\hline Massa Lemak & $\mathbf{n}$ & Mean & SD & $\mathbf{p}$ \\
\hline Dismenore primer & 38 & 30,79 & 5.56 & 0,89 \\
Tidak dismenore & 68 & 31,95 & 6,42 & \\
\hline
\end{tabular}

\section{PEMBAHASAN}

\section{Distribusi massa lemak responden.}

Berdasarkan hasil penelitian didapatkan massa lemak responden terbanyak adalah antara 21\%-33\% dengan kategori normal sebanyak $63,1 \%$. Penelitian ini berbeda dengan penelitian Pasco et al (2014) bahwa dismenore primer banyak terjadi pada responden demgan massa lemak $>33 \%$ (overweight) yaitu sebanyak $45,5 \% .^{15}$ Juga berbeda dengan penelitian Deshpande et al (2013) bahwa kejadian dismenore primer tertinggi pada responden dengan massa lemak > $33 \%$ yaitu sebanyak $89,1 \%{ }^{18}$ Penelitian juga berbeda dengan penelitian Ranasinghe et al (2013) bahwa dismenore primer banyak terjadi pada responden dengan massa lemak underweight. ${ }^{17}$

\section{Distribusi kejadian dismenore primer responden.}

Berdasarkan hasil penelitian didapatkan lebih dari setengah remaja mengalami dismenore primer ringan yaitu sebanyak 51,9\%. penelitian Dyah dan Tinah di tahun 2009, di daerah Sragen bahwa kejadian dismenore primer sebanyak $97,5 \% .{ }^{19}$ Hasil ini sejalan dengan penelitian Sophia et al pada tahun 2013, bahwa kejadian dismenore primer pada siswa SMK 10 Medan $81,3 \%{ }^{20}$ Studi ini juga sejalan dengan penelitian Fauzi (2013) bahwa kejadian dismenore primer pada siswa MTSN di Kabupaten Tanah Datar sebanyak $71 \%{ }^{21}$

\section{Hubungan massa lemak dengan kejadian dismenore primer}

Berdasarkan hasil penelitian didapatkan rerata massa lemak remaja putri yang dismenore primer yaitu $30,79 \%$ dengan kategori massa lemak normal. Rerata massa lemak remaja putri yang tidak dismenore primer yaitu $30,95 \%$ dengan kategori massa lemak normal. Hasil uji stastistik didapatkan nila $p=0,89$, berarti pada alpha $5 \%$ terlihat tidak ada perbedaan yang signifikan rata rata massa lemak antara remaja putri yang dismenore primer dengan yang tidak dismenore primer.

Hasil penelitian ini sejalan dengan penelitian Madhubala dan Kala (2012) tidak ada perbedaan persentase lemak antara remaja yang dismenore primer dengan yang tidak dismenore primer. ${ }^{16}$ Sejalan dengan penelitian Sophia et al (2013) bahwa status gizi responden yang mengalami dismenore primer sama dengan status gizi yang tidak dismenore primer yaitu sama sama pada status gizi kurang (Underweight). ${ }^{20}$ Berbeda dengan penelitian Fauzi (2013) terdapat perbedaan IMT antara siswa yang 
mengalami dismenore primer dengan yang tidak dismenore primer yaitu yang dismenore primer dengan status gizi overweight $(64,50 \%)$, sedangkan yang normal $(35,50 \%){ }^{21}$

Madhubala dan Kala (2012) menyebutkan bahwa terdapat hubungan yang bermakna antara BMI dengan dismenore primer dilihat dari segi sosial demografi dan faktor konstitusi karena kedua faktor tersebut merupakan faktor risiko terjadinya dismenore primer. Berdasarkan hasil penelitian Madhubala dan kala Kala bahwa angka kejadian dismenore primer tinggi pada remaja yang tinggal dipedesaan dibandingkan remaja yang tinggal di perkotaan. ${ }^{16} \mathrm{Hal}$ tersebut akibat pengaruh status gizi remaja lebih baik yang tinggal diperkotaan dibandingkan dengan yang tinggal dipedesaan. Ranasinghe et al (2013) juga menyebutkan terdapat hubungan yang bermakna antara BMI dengan dismenore primer dilihat dari faktor kelainan ginekologi. Ranasinghe et al (2013) melakukan pemeriksaan Ultra SonoGrafi (USG) untuk memastikan responden tidak ada kelainan ginekologi. Pada penelitian ini, hasil wawancara dengan responden tentang riwayat dismenore primer dan siklus menstruasinya tidak melakukan pemeriksaan ginekologi. ${ }^{17}$

Penelitian ini melihat sebagian kecil faktor yang mempengaruhi terjadinya dismenore primer karena keterbatasan alat dan sarana untuk pemeriksaan hormon prostaglandin yang diambil dari darah haid tidak ada. Perlunya pengkajian yang mendalam mengenai faktor risiko lainnya seperti tingkat stress remaja putri serta perlunya pemeriksaan ginekologi untuk mendapatkan hasil yang lebih valid.

Beberapa penelitian terdahulu melakukan penelitian tentang Body Mass Indeks (BMI) dan dismenore primer bukan fat mass (massa lemak) serta standar alat ukur massa lemak yang peneliti pakai menggunakan standar massa lemak international, karena BIA yang menggunakan standar Indonesia belum ada. Standar massa lemak yang ada di Indonesia berdasarkan IMT.

Bray (2004) mengatakan terdapat perbedaan massa lemak tubuh antara suku bangsa di dunia yaitu massa lemak orang Jepang akan berbeda dengan massa lemak orang Indonesia. ${ }^{22}$

\section{SIMPULAN}

Tidak terdapat hubungan yang bermakna antara massa lemak dengan kejadian dismenore primer.

\section{UCAPAN TERIMA KASIH}

Terima kasih kepada semua pihak yang telah banyak berpartisipasi dalam penelitian ini.

\section{DAFTAR PUSTAKA}

1. Gropper SS, Smith JL, Groff JL. Advance nutrition and metabolism. Edisi ke-5. USA: Wadsworth Cengage Learning; 2009 (diunduh 10 Oktober 2014). Tersedia dari: URL: HYPERLINK http://www.USA.com.

2. Niken RA. Hubungan indek masa tubuh dan persen lemak tubuh dengan sindrom pramenstruasi pada remaja putri di SMA Bina Insani Bogor. 2013 (diunduh 10 Oktober 2014). Tersedia dari: URL: HYPERLINK http://www. departemengiziipb.com

3. Cunningham FG, Leveno KJ, Bloom SL, Hauth JC, Rouse, DJ, Spong CY. William obstetry. Edisi ke23. The Mc-Graw Hill Companies; 2010.

4. Proverawati A, Misaroh S. Menarche menstruasi pertama penuh makna. Yogyakarta: Nuha Medika; 2009.

5. Gagua T, Tkeshelashvili B, Gagua D. Primary dysmenorrhea; prevalense in adolescent of Tbilisi, Georgia and risk factors. Indian J Physiol Pharmacol; Department of Physiology, S.S. Medical College. 2012; 52(4): 389-397 (diunduh 14 Oktober 2014). Tersedia dari: URL: HYPERLINK http://www.indianjphysiolpharmacol.com/389-397

6. Badan Penelitian Pengembangan Kesehatan. Riset kesehatan dasar. Jakarta: Kemenkes RI; 2013.

7. Llewellyn-Jones D. Dasar-dasar obstetri dan ginekologi. ISDN 979-492 115-7. Jakarta: Hipokrates; 2001.

8. Wirawan IMC. Dismenore. Jakarta: EGC;2007.

9. Astuti $\mathrm{NH}$. Kupas tuntas menstruasi. Yogyakarta: Milestone; 2005.

10. Gunawan D. Faktor-faktor yang berpengaruh dan perilaku remaja dalam mengatasinya (survei pada 
4 SLTP di Jakarta) (tesis). Jakarta: Fakultas Kedokteran Universitas Indonesia; 2002.

11. Nataria. Faktor-faktor yang berhubungan dengan kejadian dismenore pada mahasiswa fakultas kedokteran Universitas Pembangunan Nasional Veteran. Jakarta: Fakultas Kedokteran Universitas Pembangunan Nasional Veteran; 2011.

12. Isjwara RI, Wdjaja L, Jan WS. Comparison of body compositional indices assessed by underwater weighing, bioelectrical impedance and anthropometry in Indonesian adolescent girls. Asia Pacific Journal of Clinical Nutrition. 2007;16(4): 641-8.

13. Deurenberg $P$. Original communication: the validity of predicted body fat percentage from body mass index and from impedance in samples of five European populations. European Journal of Clinical Nutrition. 2001;55:973-9.

14. Tangchai $\mathrm{K}$, Titapant V, Wiknjosastro $\mathrm{H}$. IImu kandungan. Jakarta: Yayasan Bina Pustaka Sarwono Prawihardjo; 2005.

15. Pasco A, Kara L, Amelia G, Mark A, Lana J, Sharon L. Body mass index and Measure of body fat for defining obesityand underweight: a cross sectional, population based study. BMC. 2014:1:9 (diunduh 09 Oktober 2014). Tersedia dari: URL: HYPERLINK http://www.biomedcentral.com/20529538/1/9

16. Madhubala C, Kala J. Relation between dysmenorrhea and body mass index in adolescent with rural versus urban variation. The Journal of
Obstetrics and Gynecology of India. 2012:624 442-5.

17. Ranasinghe R, Prasanna G, Prasad K, Nalinda A, Sithira $T$, Praveen T. Relation between Body mass index (BMI) and body fat percentage, estimated by bioelectrical impedi langkaance, in a group of Sri lankan adults; cross sectional study. BMC. 2013:13:797 (diunduh 10 Oktober 2014). Tersedia dari: URL: HYPERLINK http://www.biomedcentral. com/1471 2458/13/797

18. Deshpande H, Shankar B, Priyanka D. Relationship of body mass index and body fat percentage with menstrual cycle pattern in adolescent. Pharmainter Science Publishers. 2012

19. Dyah, Tinah. Hubungan IMT dengan dismenore pada remaja putri di SMA Negeri 3 Sragen. Jurnal kebidanan. 2009.

20. Sophia F, Sori M, Jemadi. Faktor-faktor yang berhubungan dengan dismenore pada siswa SMK negeri 10 Medan tahun 2013. Medan: FKM Universitas Sumatera Utara. 2013 (diunduh 7 Oktober 2014). Tersedia dari: URL: HYPERLINK http://www.frenitasophia.co.id

21. Fauzi A. Hubungan IMT dengan dismenore pada siswi MTSN Pitalah Kab.Tanah Datar. Padang: Fakultas Kesehatan Masyarakat Universitas Andalas; 2013.

22. Bray AG. Dietary fat and obesity: a riview of animal, clinical and epidemiological studies, Universitty of north Carolina, Chapel Hill, NC, United Stage;2004. 